\title{
A new species of Exogone Ørsted, 1845 (Annelida: Syllidae: Exogoninae) from Brazilian waters
}

\author{
Marcelo Veronesi Fukudaa ; Andrezza Ribeiro Menezes-Moura ${ }^{2,3,5,6}$; Carmen Regina Parisotto Guimarães ${ }^{2,7}$ \& Christine Ruta ${ }^{3,4,5}$ \\ 1 Universidade de São Paulo (USP), Museu de Zoologia (MZUSP). São Paulo, SP, Brasil. \\ ORCID: http://orcid.org/0000-0002-7849-5563. E-mail: mvfukuda@usp.br \\ 2 Universidade Federal de Sergipe (UFS), Centro de Ciências Biológicas e da Saúde (CCBS), Departamento de Biologia (DBI), \\ Laboratório de Bentos Costeiro (LABEC). São Cristóvão, SE, Brasil. \\ ${ }^{3}$ Universidade Federal do Rio de Janeiro (UFRJ), Museu Nacional, Programa de Pós-Graduação em Zoologia. Rio de Janeiro, RJ, Brasil. \\ ${ }^{4}$ Universidade Federal do Rio de Janeiro (UFRJ), Instituto de Biologia (IB), Departamento de Zoologia. Rio de Janeiro, RJ, Brasil. \\ ORCID: http://orcid.org/0000-0001-6412-6751. E-mail: christineruta@gmail.com \\ ${ }^{5}$ Universidade Federal do Rio de Janeiro (UFRJ), Centro de Ciências da Saúde (CCS), Instituto de Biodiversidade e Sustentabilidade (NUPEM). \\ Macaé, RJ, Brasil. \\ ${ }^{6}$ ORCID: http://orcid.org/0000-0002-2195-2364. E-mail: drezzabio@gmail.com \\ 7 ORCID: http://orcid.org/0000-0003-1996-3512. E-mail: carmenparisotto@gmail.com
}

\begin{abstract}
We describe herein a new species of the abundant polychaete family Syllidae, Exogone brasiliensis sp. nov. The new species is characterized by a peculiar morphology of anterior body falcigers, with shafts and blades modified specially in chaetigers 1 and 2; falcigers until chaetiger 5 different from those of the rest of the body; and dorsal simple chaetae from midbody onwards unique in the genus, nearly straight, subdistally swollen in one side only, distally rounded. Exogone brasiliensis sp. nov. is described based on detailed morphological analyses under optical and scanning electron microscopes, and compared to its most similar congeners.
\end{abstract}

Key-Words. "Polychaeta"; South Atlantic; New species; Brazil.

\section{INTRODUCTION}

Syllidae Grube, 1850 is a highly speciose family of polychaetes, with about 73 genera and 700 species (cf. San Martín \& Aguado, 2014), and a taxonomy considered difficult. Currently, the Syllidae is divided into five subfamilies: Syllinae Grube, 1850; Autolytinae Langerhans, 1879; Exogoninae Langerhans, 1879; Eusyllinae Malaquin, 1893; and Anoplosyllinae Aguado \& San Martín, 2009.

The Exogoninae comprises syllids of small body sizes, with representatives ranging from less than 1 to $\sim 7 \mathrm{~mm}$ long, many of them interstitial, commonly found associated with mud, rocks and crevices of coral, algae and soft bottoms (San Martín, 2005). They can also be found in bathyal and abyssal depths, although in less densities. Exogone Ørsted, 1845 counts on around 40 described species (San Martín \& Aguado, 2014), eleven of which were confirmed, by formal publications, as occurring in Brazilian waters (Menezes-Moura et al., 2018): E. africana Hartmann-Schröder, 1974, E. anomalochaeta Benham, 1921, E. arenosa Perkins, 1981,
E. breviantennata Hartmann-Schröder, 1959, E. cebimar Fukuda \& Nogueira, 2014, E. dispar (Webster, 1879), E. gigas Paresque, Fukuda \& Nogueira, 2014, E. naidina Ørsted, 1845, E. naidinoides Westheide, 1974, E. rolani San Martín, 1991 and E. simplex Hartmann-Schröder, 1960 although four other species have already been cited for the Brazilian coast in "grey literature": E. aquadulcensis Pascual, Núñez \& San Martín, 1996, E. lourei Berkeley \& Berkeley, 1938, E. marisae Pascual, Núñez \& San Martín, 1996, and E. verugera (Claparède, 1868) (for further details, see Paresque et al., 2014).

In the present paper, we describe a new species of Exogone, found in great abundance in studies conducted off the Northeast and Southeast Brazilian coasts.

\section{MATERIAL AND METHODS}

Specimens were collected by 4 projects surveying different portions off the Brazilian coast. Project 'REVIZEE/South Score/Benthos' ('REVIZEE') 
sampled the southern part of the Brazilian Economic Exclusive Zone, collecting from 60-800 m deep (Amaral et al., 2004). Projects 'HABITATS - Environmental heterogeneity in the Campos Basin' ('Habitats') and 'AMBES Environmental heterogeneity in the Espírito Santo Basin and northern region of the Campos Basin' ('Ambes'), both sponsored by the Brazilian energy company PETROBRAS, studied these two large basins, located off SE Brazil, in the states of Rio de Janeiro and Espírito Santo, respectively, collecting samples from $12 \mathrm{~m}$ to $\sim 3,300 \mathrm{~m}$ deep. Finally, the Project "PETRO/MAR - Monitoring of the Continental Shelf of the States of Sergipe and Alagoas under the influence of petroleum activities" ('Petro/mar') and the Project "MARSEAL - Environmental Characterization of the Sergipe and Southern Alagoas Basin, coordinated by PETROBRAS/CENPES" ('Marseal'). Sediment was collected by means of Box Corers and van Veen grabs and immediately fixed in 4\% formalin; a few weeks later, the material was sorted and preserved in $70 \%$ ethanol. Identifications were based on morphological characters.

Length of specimens was measured from the tip of the palps to the tip of the pygidium, excluding anal cirri. Illustrations were done with the aid of a drawing tube attached to an Olympus BX $51^{\circledR}$ microscope. For the study under scanning electron microscope (SEM), specimens were dehydrated in a series of ethanol solutions, with progressively increasing concentrations (75-100\%), critical-point-dried, covered with a layer of $10-20 \mathrm{~nm}$ of gold, and analysed under the SEM at Laboratório de Microscopia Eletrônica, Instituto de Biociências, Universidade de São Paulo (IB/USP). Abbreviations for museum names are as follows: $\mathrm{AM}=$ Australian Museum, Sydney, Australia; CZUFS = Coleção de Zoologia, Universidade Federal de Sergipe, Aracaju, Brazil; MNCN = Museo Nacional de Ciencias Naturales, Madrid, Spain; MNRJP = Museu Nacional, Universidade Federal do Rio de Janeiro; MZUSP = Museu de Zoologia, Universidade de São Paulo, São Paulo, Brazil; USNM = United States National History Museum, Smithsonian Institution, Washington, DC, USA; ZMH = Zoological Museum, Universität Hamburg, Hamburg, Germany; ZUEC = Museu de Zoologia, Universidade Estadual de Campinas, Campinas, Brazil.

\section{SYSTEMATICS}

\section{Family Syllidae Grube, 1850 Subfamily Exogoninae Langerhans, 1879 Genus Exogone Ørsted, 1845}

Type species: Exogone naidina Ørsted, 1845.

Diagnosis: Mid-sized exogonines, usually with slender, smooth bodies, papillae absent. Palps entirely fused or only with terminal notch. Prostomium with three antennae of similar size or median antenna larger than lateral ones, and two pairs of eyes. Peristomium with only one pair of peristomial cirri. Peristomial, dorsal and ventral cirri throughout relatively small, ovate; dorsal cirri occa- sionally absent from chaetiger 2 . Compound chaetae as several falcigers per parapodium with distal tooth shorter than subdistal one, occasionally blades and shafts fused, or blades absent in some species; one or few chaetae per parapodium with long, spiniger-like blades, sometimes absent; dorsal and ventral simple chaetae present. Anal cirri usually slender, conspicuously longer than dorsal cirri. Pharynx with soft papillae surrounding opening and single tooth anteriorly located. Reproduction by epigamy, with ventral brooding of eggs and juveniles (Paresque et al., 2014).

\section{Exogone brasiliensis sp. nov. (Figs. 1-3)}

Exogone (Exogone) sp. 3 sensu Fukuda (2010): 144-146, Fig. 42.

Exogone (Exogone) sp. nov. C sensu Menezes (2012): 70-73, Fig. 23.

Type material: Holotype (MZUSP 3395): Campos Basin, State of Rio de Janeiro, offshore, 2246'54"S $41^{\circ} 03^{\prime} 33^{\prime \prime} \mathrm{W}, 77$ m, 02 Jul 2009. Paratypes: Campos Basin,

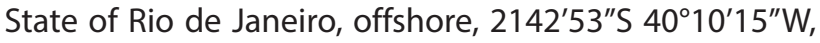
98 m: 16 specs (ZUEC-POL 21353); 223'45"S 409'59"W, 76 m: 16 specs (MNRJP 002205), 06 Jul 2009; 2246'54"S 413'33"W, $77 \mathrm{~m}: 18$ specs (MZUSP 3396, paratype 1; MZUSP 3397, 17 paratypes), 02 Jul 2009. State of Sergipe, offshore, $10^{\circ} 52^{\prime} 16^{\prime \prime} \mathrm{S} 36^{\circ} 34^{\prime} 24^{\prime \prime} \mathrm{W}-50 \mathrm{~m}$ : $1 \mathrm{spec}$ (CZUFS-POL 00001, 1 paratype).

Additional material analysed: 'REVIZEE'. State of Rio de Janeiro, 22 ${ }^{\circ} 02^{\prime} \mathrm{S} 40^{\circ} 05^{\prime} \mathrm{W}$, $93 \mathrm{~m}: 1 \mathrm{spec}$ (MZUSP 3461), 02

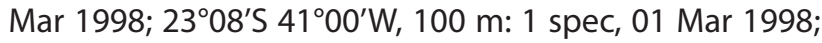
$23^{\circ} 20^{\prime} \mathrm{S} 41^{\circ} 22^{\prime} \mathrm{W}, 110 \mathrm{~m}$ : 7 specs (MZUSP 3462), 28 Feb 1998; $23^{\circ} 26^{\prime} \mathrm{S} 41^{\circ} 15^{\prime} \mathrm{W}, 145 \mathrm{~m}: 4$ specs, 27 Feb 1998; $24^{\circ} 02^{\prime} \mathrm{S} 43^{\circ} 30^{\prime} \mathrm{W}, 147 \mathrm{~m}: 1 \mathrm{spec}, 14 \mathrm{Feb} 1998$. State of Santa Catarina, $29^{\circ} 28^{\prime} \mathrm{S} 48^{\circ} 09^{\prime} \mathrm{W}, 210 \mathrm{~m}$ : $1 \mathrm{spec}, 22 \mathrm{Mar}$ 1998. 'Habitats.' State of Rio de Janeiro, Campos Basin, $21^{\circ} 09^{\prime} 9^{\prime \prime} \mathrm{S} 40^{\circ} 16^{\prime} 7^{\prime \prime} \mathrm{W}, 103 \mathrm{~m}: 26$ specs (MZUSP 3511,

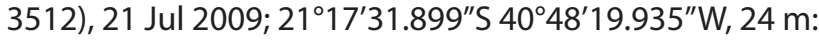
2 specs (MZUSP 3405), 08 Mar 2009; 2128'02.517"S 4056'20.614"W, $16 \mathrm{~m}: 1 \mathrm{spec}$ (MZUSP 3401), 10 Mar 2009; $21^{\circ} 45^{\prime} 13^{\prime \prime} \mathrm{S} 40^{\circ} 14^{\prime} 70^{\prime \prime} \mathrm{W}, 67 \mathrm{~m}: 20$ specs (MZUSP 3407, 3408), 14 Mar 2009; $22^{\circ} 23^{\prime} 39^{\prime \prime} \mathrm{S} 40^{\circ} 20^{\prime} 40^{\prime \prime} \mathrm{W}, 153 \mathrm{~m}: 5$ specs (MZUSP 3429), 23 Fev 2009; 2203'45"S 4009'59"W, 75 m: 13 specs (MZUSP 3433, 3434), 25 Fev 2009; 2246'54"S 4103'33"W, 78 m: 39 specs (MZUSP 3419), 22 Fev 2009; $23^{\circ} 11^{\prime} 30^{\prime \prime} \mathrm{S} 41^{\circ} 00^{\prime} 47^{\prime \prime} \mathrm{W}, 150 \mathrm{~m}: 10$ specs (MZUSP 3414), 21 Fev 2009; 2336'14"S 4121'29"W, 142 m: 2 specs (MZUSP 3411), 01 Mar 2009. 'Ambes.' State of Rio de Janeiro,

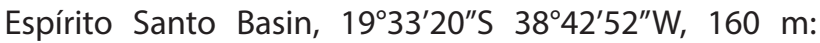
2 specs, 16 Jul 2013; 1943'14"S 39³3'34"W, 50 m: 6 specs, 14 Jul 2013; $21^{\circ} 03^{\prime} 31^{\prime \prime S} 40^{\circ} 22^{\prime} 59^{\prime \prime} \mathrm{W}, 39 \mathrm{~m}: 3$ specs, $11 \mathrm{Jul}$ 2013; 20³4'53"S 4006'27"W, 49 m: 43 specs, 12 Jul 2013;

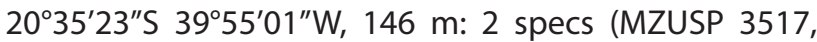
3518), $13 \mathrm{Jul}$ 2013. 'Petro/mar'. State of Alagoas, $10^{\circ} 18^{\prime} 02^{\prime \prime S}$ $36^{\circ} 07^{\prime} 04^{\prime \prime} \mathrm{W}, 30 \mathrm{~m}: 1 \mathrm{spec}(C Z U F S-P O L$ 00006), Jun 2002, $1 \mathrm{spec}$ (CZUFS-POL 00007), Dez 2002, 1 spec (CZUFS-POL 


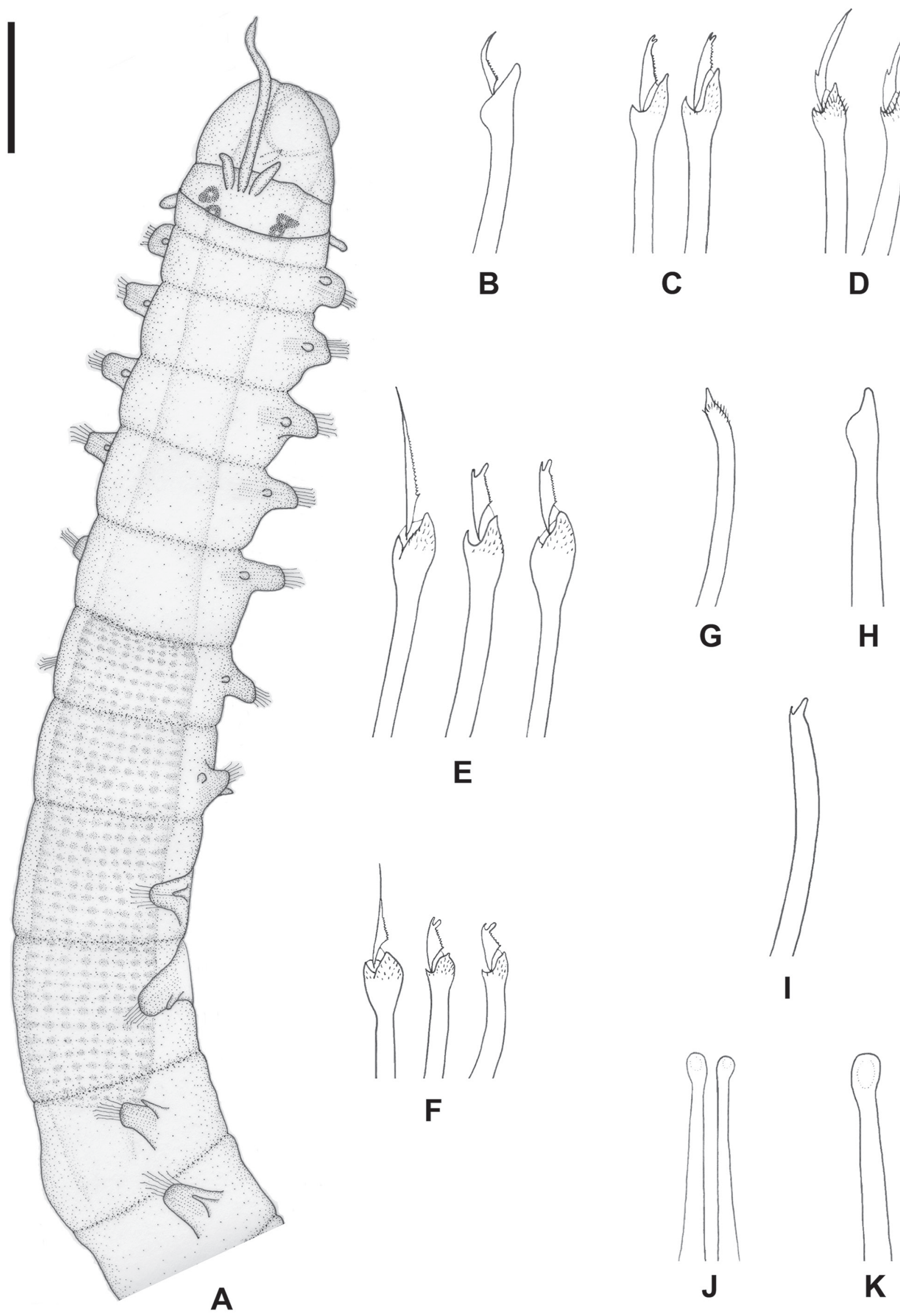

Figure 1. Exogone brasiliensis sp. nov. (A) anterior body, dorsal view; (B) compound chaeta, chaetiger 1; (C) dorsalmost compound chaetae, anterior body; (D) ventralmost compound chaetae, anterior body; (E) compound chaetae, midbody; (F) compound chaetae, posterior body; (G) dorsal simple chaeta, anterior body; (H) dorsal simple chaeta, posterior body; (I) ventral simple chaeta; (J) aciculae, anterior body; (K) acicula, posterior body. Scale bars: A, $150 \mu \mathrm{m}$; B-K, $10 \mu \mathrm{m}$. 
00008), Jun 2003. 'Petro/mar'. State of Sergipe, $10^{\circ} 57^{\prime} 03^{\prime \prime S}$ 36 50'17"W, 30 m: 1 spec (CZUFS-POL 00005), Jun 2002. 'Marseal.' State of Sergipe, $10^{\circ} 52^{\prime} 32^{\prime \prime S} 36^{\circ} 49^{\prime} 20^{\prime \prime W}, 50 \mathrm{~m}$ :
6 specs (CZUFS-POL 00002); $11^{\circ} 10^{\prime} 00^{\prime \prime S} 36^{\circ} 52^{\prime} 17^{\prime \prime} \mathrm{W}$,

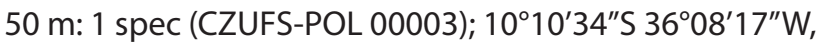
$50 \mathrm{~m}: 1$ spec (CZUFS-POL 00004).

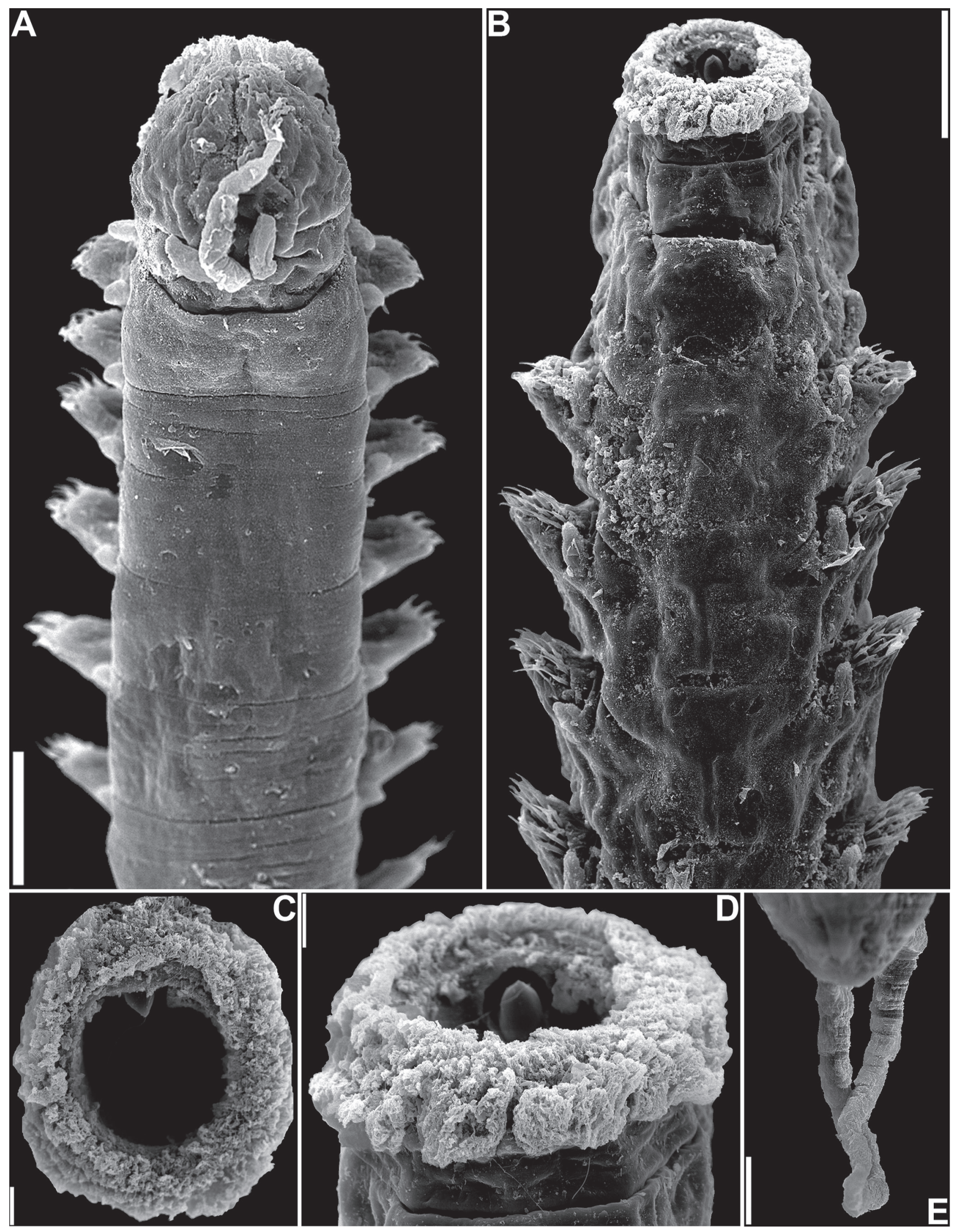

Figure 2. Exogone brasiliensis sp. nov., SEM. (A) anterior body, dorsal view; (B) anterior body, ventral view (pharynx everted); (C-D) everted pharynx, frontal and ventral view, respectively; (E) pygidium, dorsal view. Scale bars: A-B, $50 \mu \mathrm{m} ;(-D, 10 \mu \mathrm{m} ; \mathrm{E}, 20 \mu \mathrm{m}$. 
Comparative material analysed: Exogone aristata Hartmann-Schröder, 1982, Australia, Western Australia, Beacon Island, NE entrance to Goss Passage (28 $27^{\prime} 54^{\prime \prime} \mathrm{S}$ $\left.113^{\circ} 46^{\prime} 42^{\prime \prime} \mathrm{E}\right)$, in coral substrate covered by algae, $24 \mathrm{~m}$ : 1 spec (AM W26989), coll. P. Hutchings, 25 May 1994, det. G. San Martín, 2000; Beacon Island, off S end of Long Island $\left(28^{\circ} 28^{\prime} 48^{\prime \prime} \mathrm{S} 113^{\circ} 46^{\prime} 18^{\prime \prime} \mathrm{W}\right)$, in dead coral substrate covered by coralline algae, 4-5 m: 3 specs (AM W26990), coll. P. Hutchings, 25 May 1994, det. G. San Martín, 2000. Exogone dwisula Kudenov \& Harris, 1995, USA, California, Santa Maria Basin, between Purissima Point and Point Arguello (34 $\left.42^{\prime} 34^{\prime \prime} \mathrm{N} 120^{\circ} 47^{\prime} 54^{\prime \prime} \mathrm{W}\right), 100 \mathrm{~m}: 2$ specs (paratypes, AM W22190) and 3 specs (paratypes, USNM 170913), coll. 'DSR/V Diaphus', 28 Jul 1984, det. L. Harris, 1995. Exogone heterosetosa Mclntosh, 1885, Australia, Western Australia, Long Island, Goss Passage ( $28^{\circ} 28^{\prime} 18^{\prime \prime} \mathrm{S}$ $\left.113^{\circ} 46^{\prime} 18^{\prime \prime} \mathrm{W}\right)$, on dead coral covered with coralline algae and boring bivalves, $8 \mathrm{~m}$ : 10 specs (AM W27057), coll. C. Bryce, 22 May 1994, det. G. San Martín, 2000. Exogone longicornis Westheide, 1974, Ecuador, Galápagos Islands,
Santa Cruz: 1 spec (holotype, ZMH P-13618), coll. and det. W. Westheide, 1972, 1974. Exogone mompasensis Martínez, Adarraga \& San Martín, 2002, Spain, Basque Country, Guipúzcoa, San Sebastián, Punta de Mompás $\left(43^{\circ} 20^{\prime} 10^{\prime \prime} \mathrm{N} 01^{\circ} 57^{\prime} 40^{\prime \prime} \mathrm{E}\right): 12$ specs (holotype, MNCN 16.01/8710; paratypes, MNCN 16.01/10118), coll. 08 Apr 1997. Exogone rolani San Martín, 1991, USA, Florida, Port Everglades (2607'42"N 8004'48"W), 17 m: 2 specs (paratypes, USNM 101327).

Description: Body thin and elongate, longest specimen analysed ca. $6 \mathrm{~mm}$ long, 0,17 mm wide. Palps triangular, distally rounded, almost entirely fused, with conspicuous line of fusion and, sometimes, distal notch (Figs. 1A, 2A). Prostomium ovate, shorter than palps, with two pairs of nearly coalescent eyes in trapezoidal arrangement; anterior eyespots absent; antennae inserted close to each other, slightly anteriorly to anterior pair of eyes; median antenna elongated, subdistally thin, almost seven times as long as lateral antennae; lateral antennae digitiform to
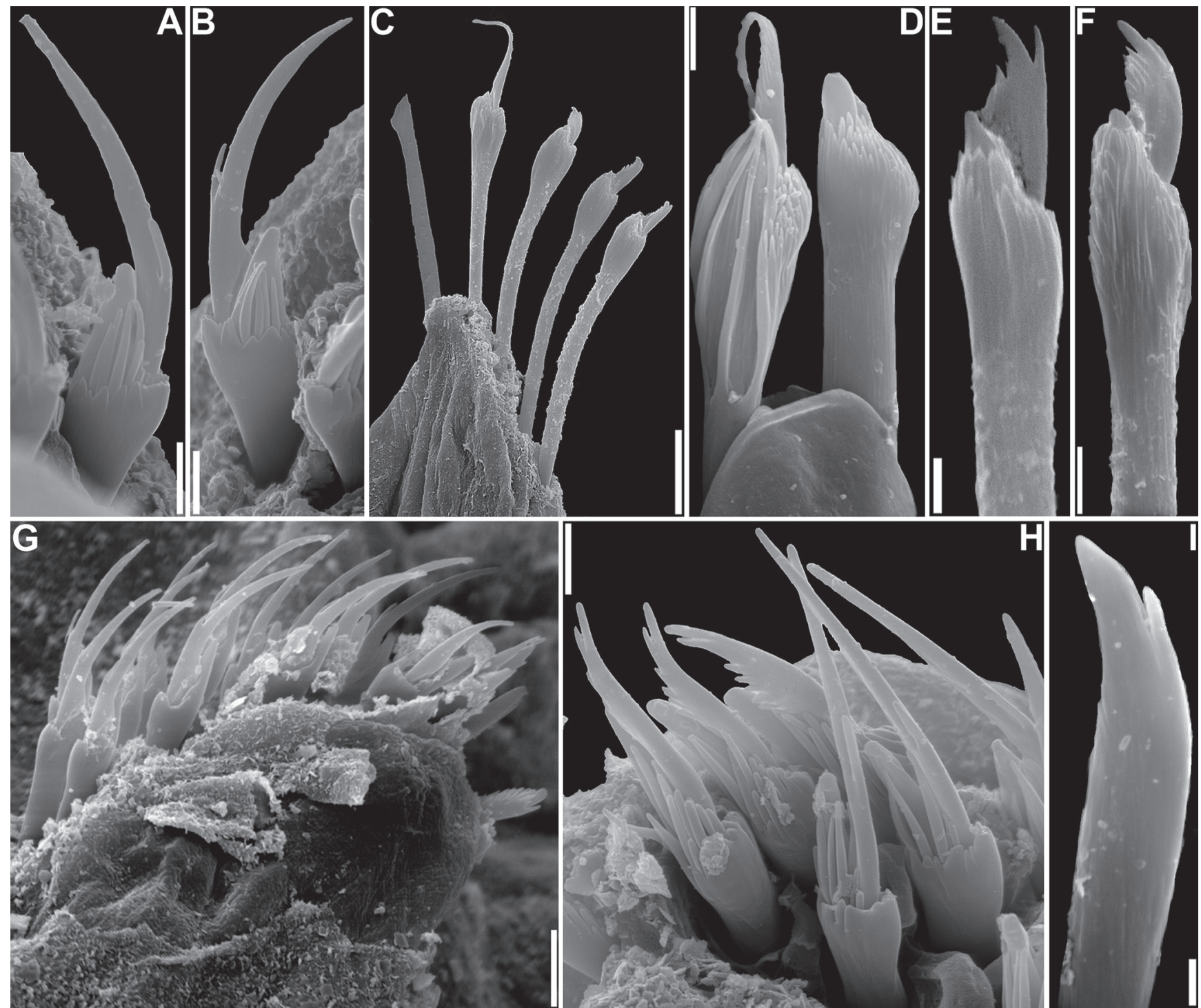

Figure 3. Exogone brasiliensis sp. nov., SEM. (A-B) ventralmost falcigers, chaetigers 2 and 3, respectively; (C) chaetae, mid- to posterior body; (D) spiniger-like and dorsal simple chaetae, posterior body; (E) ventralmost falciger, posterior body; (F) dorsalmost falciger, midbody; (G) chaetae, chaetiger 4; (H) falcigers, chaetiger 4; (I) ventral simple chaeta. Scale bars: A-B, D, F, H, $2 \mu \mathrm{m} ; \mathrm{C}, 10 \mu \mathrm{m} ; \mathrm{E}, \mathrm{I}, 1 \mu \mathrm{m} ; \mathrm{G}, 5 \mu \mathrm{m}$. 
ovate (Figs. 1A, 2A). Peristomium shorter than following chaetigers, sometimes covering posterior part of prostomium, including posterior pair of eyes; peristomial cirri ovate, slightly shorter than lateral antennae (Figs. 1A, 2A). Dorsal cirri small, rounded to ovate, shorter than peristomial cirri, present on all chaetigers (Figs. 1A, 2A); ventral cirri small, rounded to ovate, with same size as dorsal ones, or slightly smaller (Fig. 2B). Parapodia 1-5 with ca. 10 falcigers each; shafts of falcigers subdistally spinulated throughout; on chaetigers 1 and 2, shafts of the two dorsalmost falcigers modified, subdistally inflated, with acute tip (Fig. 1B); blades of anteriormost falcigers modified, 1-3 dorsalmost sometimes spinulated with short spines, distally bidentated (Figs. $1 \mathrm{C}, 3 \mathrm{H}$ ), remaining anterior body falcigers with blades progressively longer ventralwards, smooth, with subdistal tooth conspicuously longer, distal tooth reduced (Figs. 1D, 3A-B, G-H); blades 6-12 $\mu \mathrm{m}$ long, ventralmost ones approximately twice as long as dorsalmost ones. From proventricle level onwards, parapodia with 1 spiniger-like chaeta and 3-4 falcigers each; spiniger-like chaetae with subdistally enlarged shafts, with coarse spinulation forming ridges in some chaetae (Fig. 3D); blades of spiniger-like chaetae relatively short, ca. $20 \mu \mathrm{m}$ long on midbody (Figs. 1E, 3C-D), 16-12 $\mu \mathrm{m}$ on posterior body (Figs. 1F, 3D), unidentate, with short basal spinulation; blades of falcigers spinulated, bidentate, with subdistal tooth larger than distal one and subtle dorso-ventral gradation in length, blades ca. 10-8 $\mu \mathrm{m}$ long on midbody, slightly shorter on posterior body (Figs. 1E-F, 3C, E-F). Dorsal simple chaetae on anterior body slightly sigmoid, subdistally spinulated, with acute tip (Fig. 1G), protruding for short extension from parapodial lobes; from midbody onwards, dorsal simple chaetae nearly straight and subdistally enlarged on one side, with acute, rounded tip (Figs. 1H, 3C-D); ventral simple chaetae only present on posteriormost chaetigers, sigmoid, bidentate, with subdistal tooth larger than distal one (Figs. 1I, 3I). Anterior body parapodia with 2 aciculae each, distally inflated, hollow (Fig. 1J); from midbody onwards, parapodia with only 1 acicula each, similar to anterior body aciculae, but progressively thicker towards posterior body (Fig. 1K). Pygidium with a pair of long anal cirri, slightly longer than median antenna (Fig. 2E). Pharynx extending through 5-6 segments, with opening densely surrounded by cilia and conical tooth in anterior $1 / 3$ of its length (Figs. 1A, 2B-D); proventricle extending for 5-6 segments, with ca. 40 rows of muscle-cells (Fig. 1A).

Remarks: Exogone brasiliensis sp. nov. is characterized by having the two dorsalmost falcigers modified on chaetiger 1 and 2, with shafts subdistally inflated, with acute tip; falcigers of chaetigers 1-5 modified, ventralmost blades smooth, with subdistal tooth distinctly larger than the distal one, conspicuously longer than those from chaetiger 6 onwards; dorsal simple chaetae, from midbody onwards, subdistally enlarged on one side, with acute, rounded tip; and proventricle extending for 5-6 segments, with ca. 40 rows of muscle-cells.

Exogone brasiliensis sp. nov. belongs to a group of species of the genus that presents falciger blades with subdistal tooth larger than the distal one and elongated median antenna, reaching beyond tip of palps. This group also encompasses Exogone aristata, Exogone heterosetosa, Exogone longiantennata Hartmann-Schröder, 1979, Exogone longicornis, Exogone mompasensis and Exogone rostrata Naville, 1933. However, E. aristata differs from E. brasiliensis sp. nov. by the presence of aristae (large distally directed spines, usually extending beyond the tip of the chaeta) on falciger blades and on dorsal and ventral simple chaetae; E. longiantennata has no eyes neither dorsal cirri on chaetiger 2; both E. longicornis and E. rostrata present shafts of spiniger-like chaetae of chaetiger 1 with a subdistal thickening forming a triangular process, which is absent in E. brasiliensis sp. nov. Finally, E. heterosetosa and E. mompasensis differ from E. brasiliensis sp. nov. by having spiniger-like chaetae modified, with shafts distally inflated and strongly spinulated, and relatively short, triangular blades.

Exogone dwisula and Exogone naidina also have compound chaetae of the first chaetigers with modified blades. However, different from Exogone brasiliensis sp. nov., modified falciger blades in both these species present no denticle corresponding to the distal tooth, and they show a pronounced spine at the base of the blades, sometimes distally directed, giving the blades the appearance of a "can opener" (Kudenov \& Harris, 1995; San Martín, 2003, 2005). In addition, both E. dwisula and E. naidina have dorsal simple chaetae on posterior body sigmoid, subdistally inflated and spinulated, with acute tip, while E. brasiliensis sp. nov. presents dorsal simple chaetae straighter than usual for the genus, subdistally swollen only on one side, distally rounded.

Perhaps the most similar species to Exogone brasiliensis sp. nov. is Exogone rolani, by having enlarged median antenna, dorsal cirri on all chaetigers, falcigers with subdistal tooth larger than distal one, and shafts of falcigers on chaetigers 1-5 modified, with large, pointed, oblique tip (Paresque et al., 2014). However, E. rolani differs from E. brasiliensis sp. nov. by having spiniger-like chaetae on all chaetigers and with longer blades than those of E. brasiliensis sp. nov., up to $25 \mu \mathrm{m}$ long, while spiniger-like chaetae are absent from the first 5 chaetigers of $E$. brasiliensis sp. nov., and the longer blades are up to $20 \mu \mathrm{m}$ long. Furthermore, E. rolani presents dorsal simple chaetae with a more common morphology to the genus, sigmoid, subdistally spinulated, with acute tip (see Paresque et al., 2014, figs. 7C, G, K), while, from midbody onwards, dorsal simple chaetae of $E$. brasiliensis sp. nov. are quite unique, nearly straight and subdistally swollen on one side only, distally rounded. Finally, despite extending for a similar number of chaetigers, the proventricle in E. brasiliensis sp. nov. presents more muscle cell rows than that of E. rolani (ca. $40 \times$ ca. 29).

Etymology: This species was named brasiliensis because the type locality is in Brazil and the species presents a large distribution along the coast.

Distribution: Atlantic Ocean: Brazil (Alagoas, Sergipe, Espírito Santo, Rio de Janeiro and Santa Catarina). 


\section{ACKNOWLEDGMENTS}

We are grateful to CENPES/PETROBRAS and all the staff involved in the collections of the material herein analysed, to the Project 'PETRO/MAR' and 'MARSEAL' teams. We also thank Enio Matos and Phillip Lenktaitis (IB/USP) for preparing and photographing animals under the SEM, and all the staff of the museums housing specimens involved in this paper, specially Angelika Brandt $(\mathrm{ZMH})$, Javier Sánchez Almazán (MNCN), Joana Zanol (MNRJP) Karen Osborn and Geoff Keel (USNM), Stephen Keable (AM), and Tatiana Steiner (ZUEC). Financial support to $C R$ and the Masters fellowship for ARMM were provided by Conselho Nacional de Desenvolvimento Científico e Tecnológico (CNPq), through the Programa de Capacitação em Taxonomia (PROTAX), process number 562343/2010-5. MVF received a postdoc fellowship from the São Paulo Research Foundation (FAPESP processes 2010/19424-7; 2014/11549-6).

\section{REFERENCES}

Aguado, M.T. \& San Martín, G. 2009. Phylogeny of Syllidae (Polychaeta) based on morphological data. Zoologica Scripta, 38: 379-402. DOI

Amaral, A.C.Z.; Lana, P.C.; Rizzo, A.E.; Steiner, T.M.; Pardo, E.V.; Santos, C.S.G.; Carvalho, A.C.; Wagner, M.F.R.; Garrafoni, A.R.S.; Brasil, A.C.; Ribeiro, Z.; Nogueira, J.M.M.; Abbud, A.; Rossi, M.C.S. \& Fukuda, M.V. 2004. Filo Annelida - Classe Polychaeta. In: Amaral, A.C. \& RossiWongtschowski, C.L.D.B. (Eds.). Biodiversidade Bentônica da Região Sudeste-Sul do Brasil - Plataforma Externa e Talude Superior. Série Documentos Revizee: Score Sul, MMA, p. 114-125. Disponível em: http://www.mma.gov.br/estruturas/revizee/ arquivos/revizee bentos.pdf.

Benham, W.B. 1921. Polychaeta. Australasian Antarctic Expedition 1911-14 under the leadership of Sir Douglas Mawson, D.Sc. B.E. Scientific Reports, Series ( - Zoology and Botany, 6(3): 1-128.

Berkeley, E. \& Berkeley, C. 1938. Notes on polychaeta from the coast of western Canada. 2. Syllidae. The Annals and Magazine of Natural History, including Zoology, Botany and Geology, Series 11, 1:33-49.

Claparède, E. 1868. Les annélides chétopodes du Golfe de Naples. Mémoires de la Société de physique et d'histoire naturelle de Genève, 19: 313-584.

Fukuda, M.V. 2010. Contribuição ao conhecimento taxonômico dos silídeos (Polychaeta: Syllidae) da região sudeste-sul do Brasil. (Ph.D. Thesis). Universidade de São Paulo, São Paulo.

Fukuda, M.V. \& Nogueira, J.M.M. 2014. A new species of Exogone (Syllidae: Exogoninae) from off the state of São Paulo (south-east Brazil). Memoirs of Museum Victoria, 71: 79-84.

Grube, A.E. 1850. Die Familien der Anneliden. Archiv für Naturgeschichte, 16(1): 249-364.

Hartmann-Schröder, G. 1959. Zur ökologie der polychaeten des mangroveesterogebiets von El Salvador. Beiträge zur Neotropical Fauna, 1: 70-183.

Hartmann-Schröder, G. 1960. Polychaeten aus dem Roten Meer. Kieler Meeresforschungen, 16: 69-125.

Hartmann-Schröder, G. 1974. Zur Kenntnis des Sublitorals der Afrikanischen Zwischen Angola und Kap de Guten Hoffnung und der Afrikanischen Ostküste von Südafrika und Mocambique unter Besonder Berücksichtigung der Polychaeten und Ostracoden. Teil 2. Die Polycheten des Untersuchungsgebietes. Mitteilungen aus dem Hamburgischen Zoologischen Museum und Institut, 69: 95-228.
Hartmann-Schröder, G. 1979. Die Polychaeten der tropischen Nordwestküste Australiens (zwischen Derby im Norden und Port Hedland im Süden). In: Hartmann-Schröder, G. \& Hartmann, G. (Eds.). Zur Kenntnis des Eulitorals der australischen Küsten unter besonderer Berücksichtigung der Polychaeten und Ostracoden. Teil 2 und Teil 3. Mitteilungen aus dem Hamburgischen Zoologischen Museum und Institut, 76: 75-218.

Hartmann-Schröder, G. 1982. Die Polychaeten der subtropisch-antiborealen Westküste Australiens (zwischen Cervantes im Norden und Cape Naturaliste im Süden). Teil 8. In: Hartmann-Schröder, G. \& Hartmann, G. (Eds.). Zur kenntnis des eulitorals der australischen Küsten unter besonderer Berücksichtigung der Polychaeten und Ostracoden. Mitteilungen aus dem Hamburgischen Zoologischen Museum und Institut, 79: 51-118.

Kudenov, J.D. \& Harris, L.H. 1995. Family Syllidae Grube, 1850. In: Blake, J.A.; Hilbig, B. \& Scott, P.H. (Eds.). Taxonomic Atlas of the Benthic Fauna of the Santa Maria Basin and Western Santa Barbara Channel 5 - The Annelida, part 2. Polychaeta: Phyllodocida (Syllidae an scale-bearing families), Amphinomida and Eunicida. Santa Barbara, San Barbara Museum of Natural History. p. 1-97.

Langerhans, P. 1879. Die Wünfauna von Madeira. Zeitschrift für Wissenschaftliche Zoologie, 33: 513-592.

Malaquin, A. 1893. Recherches sur les syllidiens. Morphologie, anatomie, reproduction, développement. Mémoires de la Société des Sciences, de I'Agriculture et des Arts de Lille, 4ème série, 18: 1-477.

Martínez, J.; Adarraga, I. \& San Martín, G. 2002. Exogone (Exogone) mompasensis (Exogoninae: Syllidae: Polychaeta), a new species of the Iberian Peninsula. Proceedings of the Biological Society of Washington, 115(3): 676-680.

McIntosh, W.C. 1885. Report on the Annelida Polychaeta collected by the H.M.S. Challenger during the years 1873-76. In: Report on the Scientific Results of the Voyage of H.M.S. Challenger during the Years 1873-1876 under the command of the Captain George S. Nares, R.N.; F.R.S. and the Late Captain Frank Tourle Thomson, R.N. Zoology. London, Longmans \& Co. v. 12, p. 1-554.

Menezes, A.R. 2012. Composição das subfamílias de Syllidae (Polychaeta) e taxonomia de Exogoninae (Syllidae) da plataforma continental SergipeAlagoas (Nordeste, Brasil). (M.Sc. Dissertation). Universidade Federal do Rio de Janeiro, Macaé.

Menezes-Moura, A.R.; Gomes, M.A.B.; Fukuda, M.V. \& Ruta, C. 2018. Checklist of the species of Syllidae (Annelida: Phyllodocida) recorded in Brazil. Revista Brasileira de Zoociências, 19(3): 104-147.

Naville, A. 1933. Quelques formes épitoques d'annélides polychètes nouvelles ou peu connues pêchees a la lumière dans la baie de Banyuls. Annales des Sciences Naturelles, Zoologie, Série 10, 16: 171-208.

Ørsted, A.E. 1845. Ueber die Entwicklung der Jungen bei einer Annelide und über änveren Untersuchiede zwichen beiden Geschechtern. Archiv für Naturgeschichte, 11(1): 20-25.

Paresque, K.; Fukuda, M.V. \& Nogueira, J.M.M. 2014. The genus Exogone (Polychaeta: Syllidae) from the Brazilian coast, with the description of a new species. Zootaxa, 3790(4): 501-533.

Pascual, M.; Nuñez, J. \& San Martín, G. 1996. Exogone (Polychaeta: Syllidae: Exogoninae) endobiontics of sponges from the Cannary and Madeira islands, with descriptions of two new species. Ophelia, 45: 67-80.

Perkins, T.H. 1981. Syllidae (Polychaeta), principally from Florida, with descriptions of a new genus and twenty-one new species. Proceeding of the Biological Society of Washington, 92(4): 1080-1172.

San Martín, G. 1991. Grubeosyllis and Exogone (Exogoninae, Syllidae, Polychaeta) from Cuba, the Gulf of Mexico, Florida and Puerto Rico, with a revision of Exogone. Bulletin of Marine Science, 49(3): 715-740. 
San Martín, G. 2003. Anellida Polychaeta Il: Syllidae. Madrid, Museo Nacional de Ciências Naturales, CSIC. p. 1-554. (Fauna Ibérica vol. 21).

San Martín, G. 2005. Exogoninae (Polychaeta: Syllidae) from Australia with the description of a new genus and twenty-two new species. Records of the Australian Museum, 57: 39-152.

San Martín, G. \& Aguado, M.T. 2014. Family Syllidae. In: Schmidt-Rhaesa, A. (Ed.). Phyllodocida: Nereidiformia. Handbook of Zoology, Annelida. A
Natural History of the Phyla of the Animal Kingdom. Berlin, Verlag Walter de Gruyter GmbH \& Co. p. 1-52.

Webster, H.E. 1879. Annelida Chaetopoda of the Virginian coast. Transactions of the Albany Institut, 9: 201-272.

Westheide, W. 1974. Interstitial polychaetes from Brazilian sandy beaches. Mikrofauna Meersbodens, 31: 3-16. 